\title{
РІВЕНЬ ВІТАМІНІВ У КРОВІ БУГАЙЦІВ ЗА ЕКСПЕРИМЕНТАЛЬНОГО ХРОНІЧНОГО КАДМІЄВОГО ТОКСИКОЗУ
}

\author{
Ю. Ю. Лавришин, аспірант, \\ Б. В. Гутий, д-р вет. наук, професор
Львівський національний університет ветеринарної медицини та біотехнологій імені С.3. Гжицького, \\ вул. Пекарська, 50, м. Львів, 79010, Україна
}

\begin{abstract}
Надходження Кадмію пов'язане з екологічним ризиком для організму через кумулятивну його токсичність щодо органів $i$ систем. Воно спричинює зниження інтенсивності росту та продуктивності тварин. Накопичення згаданого вище важкого металу в компонентах природного середовища збільшує небезпеку його надходження в організм і становить загрозу для здоров'я тварини. Саме тому метою роботи було вивчити вплив кадмієвого навантаження на рівень вітамінів А $і$ Е у крові молодняку великої рогатої худоби. Дослідження проводились на базі фрермерського господарства с. Іванівиі Жидачівського району Львівськой області на десяти бугайчях шестимісячного віку, украӥнської чорно-рябої молочної породи, які були сформовані у дві групи по п'яти тварин у кожній: контрольну та дослідну. Бугайці контрольної групи знаходились на звичайному рачіоні. Бугайцям дослідної групи згодовували з кормом хлорид кадмію у дозі 0,04 мг/кг маси тіла тварини. Дослід тривав упродовж 30-и діб. Для проведення досліджень дотримувалися правил, обов'язкових з виконання зоотехнічних дослідів щодо підбору та утримання тваринаналогів у групи, технологї̈ заготівлі, використання й обліку спожитих кормів. Раціон тварин був збалансований за поживними та мінеральними речовинами, які забезпечували їх потребу в основних елементах живлення. Експерименти проводили з дотриманням принципів гуманності, викладених у директиві Свропейської Спільноти. Результати експерименту вказують на те, щзо кадмій істотно впливає на прочеси метаболізму клітин печінки, таким чином стимулюючи процеси перекисного окиснення ліпідів та пригнічуючи активність неензимної ланки системи антиоксидантної системи, а саме на рівень вітамінів $A$ і Е у крові молодняку великої рогатої худоби. Найнижчим рівень вітамінів $A$ i E був у крові дослідної групи бугайців на 20-ту добу досліду, де відповідно коливався у межах 0,62 $\pm 0,035 i$

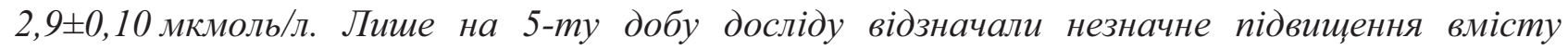
вітамінів, що можливо зумовлено захисною дією організму бугайців на надходження кадмію хлориду у токсичній дозі. Проведені дослідження дали можливість глибше розкрити патогенез токсичної дії Кадмію на організм молодняку великої рогатої худоби та використати ці дані для розроблення антидоту при кадмієвій інтоксикації.
\end{abstract}

Ключові слова: ТОКСИКОЛОГІЯ, БУГАЙЦІ, КАДМІЙ, ВІТАМІНИ А I Е, АНТИОКСИДАНТНА СИСТЕМА.

Кадмій - один із найбільш токсичних важких металів. Його відносять до другого класу небезпеки - високонебезпечні речовини. Як і багато інших важких металів, кадмій має виражену тенденцію до накопичення в організмі: період його напіввиведення становить 10-35 років. До 50 років його загальна кількість в організмі людини може досягати 30-50 мг. Кадмій в організмі накопичується у нирках (30-60 \% від усієї кількості) і печінці (20-25\%). Також кадмій знаходять у підшлунковій залозі, селезінці, трубчастих кістках, інших органах $\mathrm{i}$ тканинах [1-3]. 
У зв'язку з інтенсивними викидами промислових підприємств забруднення кадмієм навколишнього середовища постійно зростає. Внаслідок цього збільшується також забруднення ним грунтів і харчових продуктів, які на них вирощують [4].

Результати багатьох експериментальних робіт вказують на те, що в організмі ссавців кадмій проявляє токсичний вплив на низку органів і систем, зокрема на серцево-судинну, статеву, видільну, дихальну, систему гемопоезу, опорно-рухову систему [5, 6]. До найнебезпечніших впливів належать канцерогенні та мутагенні ефекти цього елемента. Відомо, що за умов інтоксикації організму тварин сполуками кадмію виникає анемія, пригнічення функціонального стану імунної системи та інші розлади в процесах кровотворення [3, 7].

Метою роботи було вивчити вплив кадмієвого токсикозу на рівень вітамінів А і Е у крові молодняку великої рогатої худоби.

Матеріали і методи. Дослідження проводились на базі фермерського господарства с. Іванівці Жидачівського району Львівської області на 10 бугайцях шестимісячного віку, української чорно-рябої молочної породи, які були сформовані у 2 групи по 5 тварин у кожній: контрольну та дослідну. Бугайці контрольної групи знаходились на звичайному раціоні. Бугайцям дослідної групи згодовували 3 кормом хлорид кадмію у дозі 0,04 мг/кг маси тіла тварини.

Для проведення досліджень дотримувалися правил, обов'язкових 3 виконання зоотехнічних дослідів щодо підбору та утримання тварин-аналогів у групи, технології заготівлі, використання й обліку спожитих кормів. Раціон тварин був збалансований за поживними та мінеральними речовинами, які забезпечували їх потребу в основних елементах живлення.

Утримання, годівлю, догляд та усі маніпуляції з тваринами здійснювали згідно 3 Європейською конвенцією «Про захист хребетних тварин, які використовуються для експериментальних і наукових цілей» (Страсбург, 1986 р.) і «Загальних етичних принципів експериментів на тваринах», ухвалених Першим Національним конгресом з біоетики (Київ, 2001). Експерименти проводили 3 дотриманням принципів гуманності, викладених у директиві Європейської Спільноти.

Дослід тривав упродовж 30-и діб. Кров для аналізу брали з яремної вени на 5-, 10-, 15, 20-, і 30-ту добу досліду.

Вміст вітамінів А і Е у крові тварин визначали за допомогою високоефективної рідинної хроматографії на хроматографі «Міліхром-4» [8].

Аналіз результатів досліджень проводили за допомогою пакету програм Statistica 6.0. Вірогідність різниць оцінювали за t-критерієм Стьюдента. Результати середніх значень вважали статистично вірогідними при $*-\mathrm{P}<0,05, * *-\mathrm{P}<0,001$ (ANOVA)

Результати й обговорення. На основі попередніх досліджень встановлено, що Кадмій при потраплянні в організм молодняку великої рогатої худоби активізує інтенсивність радикалоутворення та посилює процеси перекисного окиснення ліпідів [6]. У результаті чого пригнічується ензимна ланка системи антиоксидантного захисту організму тварин. Саме тому важливим $є$ також дослідження неензимної ланки даної системи, до якої входять вітаміни, які характеризуються високими донорськими властивостями, оскільки знижують кількість вільного кисню у клітині, шляхом активації його утилізації та здатністю відновлювати радикали ліпідів. Усі вони відносяться до «прямих» антиоксидантів, оскільки безпосередньо взаємодіють 3 активними формами кисню, продуктами перекисного окиснення ліпідів та вільними радикалами

Одним із основних вітамінів, які володіють антиоксидантними властивостями є вітамін Е. Механізм фармакологічної дії вітаміну Е полягає у тому, що він запобігає окисненню жирів, жирних кислот та стеринів. Вітамін Е стабілізує клітинні мембрани та внутріклітинні 
утворення, що є необхідною передумовою захисту ядерного хроматину та ДНК від руйнівної дії вільних радикалів [9, 10].

Рівень вітаміну Е у крові бичків за хронічного кадмієвого токсикозу наведений у таблиці 1. Встановлено вірогідне підвищення вітаміну Е у крові дослідної групи бугайців на 5-ту добу досліду, яким згодовували з кормом хлорид кадмію у дозі 0,04 мг/кг маси тіла тварини. У подальшому рівень вітаміну Е продовжував знижуватися, де порівняно 3 контрольною групою на 10-ту добу досліду знизився на 9,5\% відповідно. На 15-ту добу

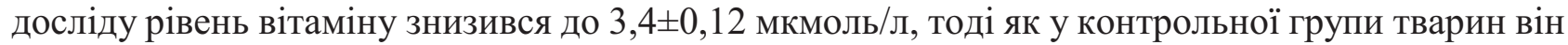

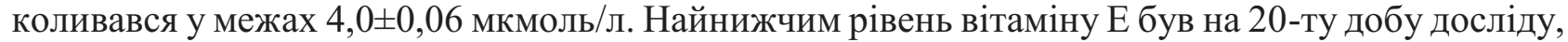
де порівняно з показниками контрольної групи він знизився на 32,6\%. На 30-ту добу рівень вітаміну порівняно з попередньою добою зріс, однак при порівнянні з контрольною групою був нижчим на 17,9\%.

Табличя 1

Рівень вітаміну Е у крові бичків за хронічного кадмієвого токсикозу; $(\mathrm{M} \pm \mathrm{m}, \mathrm{n}=5)$

\begin{tabular}{|c|c|c|}
\hline \multirow{2}{*}{$\begin{array}{c}\text { Час дослідження крові } \\
\text { (доби) }\end{array}$} & \multicolumn{2}{|c|}{ Вітамін Е (мкмоль/л) } \\
\cline { 2 - 3 } & Групи тварин \\
\hline Вихідні величини & $4,1 \pm 0,05$ & Дослідна \\
\hline П'ята доба & $4,0 \pm 0,07$ & $4,0 \pm 0,07$ \\
\hline Десята доба & $4,2 \pm 0,08$ & $4,4 \pm 0,10^{*}$ \\
\hline П'ятнадцята доба & $4,0 \pm 0,06$ & $3,8 \pm 0,09^{*}$ \\
\hline Двадцята доба & $4,3 \pm 0,09$ & $3,4 \pm 0,12^{*}$ \\
\hline Тридцята доба & $3,9 \pm 0,06$ & $3,9 \pm 0,10^{* *}$ \\
\hline
\end{tabular}

Примітка: ступінь вірогідності порівняно з даними контрольної групи - p<0,05 - *, p<0,001 - **

Вітамін Е (токоферол) охороняє вітамін А від окиснення як в кишечнику, так і в тканинах. Якщо $є$ нестача вітаміну Е, то вітамін А не буде засвоюватись у відповідній кількість, і тому ці два вітаміни потрібно приймати разом [11].

Вітамін А $є$ потужним акцептором перекисних радикалів, що пов'язано із його здатністю активно перехоплювати пероксидні сполуки. Антиоксидантні ефекти даного вітаміну мають також і опосередкований характер, оскільки ретинол, як відомо, бере активну участь у синтезі сірковмісних амінокислот в організмі, зокрема L-цистеїну. Останній $\epsilon$, водночас, структурним компонентом глутатіону і, завдяки наявності у їі складі функціонально високоактивної сульфгідрильної групи - визначальною в реалізації його антиоксидантних ефектів [12].

Вміст вітаміну А у крові бугайців за умов згодовування хлориду кадмію наведений у таблиці 2. Слід відзначити, що внаслідок дії Кадмію порушується засвоєння каротину та перетворення його у ретинол, що негативно відбивається на здоров'ї тварин. Так, у дослідах на телятах чорно-рябої породи було виявлено, що Кадмій перешкоджає нормальному засвоєнню каротину, в результаті руйнування вітаміну А в рубці.

Таблиия 2

Рівень вітаміну А у крові бичків за хронічного кадмісвого токсикозу; $(\mathrm{M} \pm \mathrm{m}, \mathrm{n}=5)$

\begin{tabular}{|c|c|c|}
\hline \multirow{2}{*}{$\begin{array}{c}\text { Час дослідження крові } \\
\text { (доби) }\end{array}$} & \multicolumn{2}{|c|}{ Вітамін А (мкмоль/л) } \\
\cline { 2 - 3 } & Конупи тварин \\
\hline Вихідні величини & $0,83 \pm 0,029$ & Дослідна \\
\hline П'ята доба & $0,79 \pm 0,031$ & $0,80 \pm 0,030$ \\
\hline Десята доба & $0,85 \pm 0,025$ & $0,83 \pm 0,015$ \\
\hline П'ятнадцта доба & $0,81 \pm 0,020$ & $0,74 \pm 0,020$ \\
\hline Двадцята доба & $0,80 \pm 0,026$ & $0,62 \pm 0,035^{* *}$ \\
\hline Тридцята доба & $0,78 \pm 0,024$ & $0,69 \pm 0,018^{*}$ \\
\hline
\end{tabular}

Примітка: ступінь вірогідності порівняно з даними контрольної групи $-\mathrm{p}<0,05-{ }^{*}, \mathrm{p}<0,001-{ }^{* *}$ 
Встановлено вірогідне зниження вітаміну А у крові бугайців дослідної групи на 15-ту добу досліду, де порівняно 3 контрольною групою тварин він знизився на 17,3\%. У подальшому рівень вітаміну А продовжував знижуватися і на 20-ту жобу досліду досягав $0,62 \pm 0,035$ мкмоль/л, тоді як у контролі даний показник становив $0,80 \pm 0,026$ мкмоль/л. На 30 ту добу досліду рівень вітаміну А у крові дослідної групи знизився на 11,5\%.

Таким чином згодовування бугайцям хлориду кадмію у дозі 0,04 мг/кг маси тіла тварини, призводить до пригнічення неензимної ланки системи антиоксидантної системи організму тварин, на що вказує зниження рівня вітамінів А і Е.

\title{
В И С Н О В К И
}

1. Згодовування бугайцям хлориду кадмію у дозі 0,04 мг/кг маси тіла протягом 30 діб спричинило розвиток хронічного кадмієвого токсикозу. Згодовування бугайцям хлориду кадмію у вказаній дозі зумовило вірогідне зниження рівня вітамінів А і Е.

2. Проведені дослідження дали можливість глибше розкрити патогенез токсичної дії Кадмію на організм бугайців та використати ці дані для розроблення антидоту при кадмієвій інтоксикації.

Перспективи досліджень. Отримані дані будуть застосовані у подальшому вивченні системи антиоксидантного захисту та процесів перекисного окиснення ліпідів крові бугайців для розробки антидотного препарату для лікування тварин при кадмієвому токсикозі.

\section{LEVELS OF VITAMINS IN BLOOD OF YOUNG BULLS BY EXPERIMENTAL CHRONIC CARDIUM TOXICOSIS}

\author{
Y. Y. Lavryshyn, B. V. Gutyj
}

Lviv National University of Veterinary Medicine and Biotechnologies named after S. Z. Gzhytskyi 50, Pekarska str., Lviv, 79010, Ukraine

\section{S U M M A R Y}

Cadmium exposure is associated with ecological risk to the body through cumulative toxicity to organs and systems. It causes a decrease in the intensity of the growth and productivity of animals. Accumulation of this heavy metal in the components of the natural environment increases the risk of its introduction into the body and poses a threat to animal health. That is why the purpose of the work was to study the effect of cadmium load on the level of vitamins A and E in the blood of young animals of cattle. The research was carried out on the basis of the farm village. Ivanivtsi Zhydachiv district of Lviv region on ten young bulls of six months old, Ukrainian black-and-white milk breed, which were formed into two groups of five animals in each: control and experimental. Bulls of the control group were in the usual diet. Young bulls of the experimental group were fed feed with cadmium chloride at a dose of $0.04 \mathrm{mg} / \mathrm{kg}$ body weight of the animal. The study lasted for 30 days. To conduct research, the rules were followed for the implementation of zootechnical experiments on the selection and maintenance of animal-analogues in the group, harvesting technology, use and accounting of consumed feed. The animal's diet was balanced by nutrients and minerals that provided them with essential nutrients. The experiments were carried out in accordance with the principles of humanity laid down in the directive of the European Community. The results of the experiment indicate that cadmium significantly affects the metabolism of liver cells, thus stimulating the processes of lipid peroxidation and suppressing the activity of the non-limiting chain of the antioxidant system, namely the level of vitamins $\mathrm{A}$ and $\mathrm{E}$ in the blood of young cattle. The lowest level of vitamins $\mathrm{A}$ and $\mathrm{E}$ was in the blood of the experimental group of young bulls on the 20th day of the experiment, which respectively fluctuated within the range of $0.62 \pm 0.035$ and $2.9 \pm 0.10$ 
$\mu \mathrm{mol} / \mathrm{L}$. Only on the 5 th day of the experiment was noted a slight increase in the content of vitamins, which is possibly due to the protective effect of the bulls organism on the intake of cadmium chloride in a toxic dose. The conducted studies made it possible to reveal more deeply the pathogenesis of the toxic effect of Cadmium on the organism of young cattle and use these data to develop an antidote for cadmium intoxication.

Keywords: TOXICOLOGY, BULLS, KADMIUM, VITAMINS A AND E, ANTIOXIDANT SYSTEM.

\title{
УРОВЕНЬ ВИТАМИНОВ В КРОВИ БЫЧКОВ ПРИ ЭКСПЕРИМЕНТАЛЬНОМ ХРОНИЧЕСКОМ КАДМИЕВОМ ТОКСИКОЗЕ
}

\author{
Ю. Ю. Лавришин, Б. В. Гутый \\ Львовский национальный университет ветеринарной медицины и биотехнологий \\ имени С.3. Гжицкого, \\ ул. Пекарская, 50, г. Львов, 79010, Украина
}

А Н Н О Т А И Я

Поступления кадмия связано с экологическим риском для организма через кумулятивную его токсичность в отношении органов и систем. Он вызывает снижение интенсивности роста и продуктивности животных. Накопление упомянутого выше тяжелого металла в компонентах природной среды увеличивает опасность его поступления в организм и представляет угрозу для здоровья животного. Именно поэтому целью работы было изучить влияние кадмиевой нагрузки на уровень витаминов А и Е в крови молодняка крупного рогатого скота. Исследования проводились на базе фермерского хозяйства с. Иванивци Жидачевского района Львовской области на десяти бычках шестимесячного возраста, украинской черно-рябой молочной породы, которые были сформированы в две группы по пять животных в каждой: контрольную и опытную. Бычки контрольной группы находились на обычном рационе. Бычкам опытной группы скармливали с кормом хлорид кадмия в дозе 0,04 мг/кг массы тела животного. Опыт продолжался в течение 30-и дней. Для проведения исследований придерживались правил, обязательных по выполнению зоотехнических опытов по подбору и содержанию животных-аналогов в группах, технологии заготовки, использованию и учета потребленных кормов. Рацион животных был сбалансирован по питательным и минеральным веществам, которые обеспечивали их потребность в основных элементах питания. Эксперименты проводили с соблюдением принципов гуманности, изложенных в директиве Европейского Сообщества. Результаты эксперимента показывают, что кадмий существенно влияет на процессы метаболизма клеток печени, таким образом стимулируя процессы перекисного окисления липидов и подавляя активность неензимного звена системы антиоксидантной системы, а именно на уровень витаминов А и Е в крови молодняка крупного рогатого скота. Низким уровень витаминов А и Е был в крови опытной группы бычков на 20-е сутки опыта, где в соответствии колебался в пределах 0,62 $\pm 0,035$ и $2,9 \pm 0,10$ мкмоль/л. Только на 5-е сутки опыта отмечали незначительное повышение содержания витаминов, что обусловлено защитным действием организма бычков на поступление кадмия хлорида в токсической дозе. Проведенные исследования позволили глубже раскрыть патогенез токсического действия кадмия на организм молодняка крупного рогатого скота и использовать эти данные для разработки антидота при кадмиевой интоксикации.

Ключевые слова: ТОКСИКОЛОГИЯ, БЫЧКИ, КАДМИЙ, ВИТАМИНЫ А И Е, АНТИОКСИДАНТНАЯ СИСТЕМА. 


\section{Л I T E P A T Y P A}

1. Токсикологічний вплив солей свинцю та кадмію на біоіхімічні показники у лабораторних тварин / Д. О. Мельничук, І. М. Трахтенберг, Н. М. Мельникова, та ін. // Науковий вісник НАУ. - 2002. - № 55. - С. 117-119.

2. Мельничук Д. О. Вікові особливості кумуляції кадмію в органах отруєних щурів і зміни показників кислотнолужного стану крові за різних умов антиоксидантного захисту організму / Д. О. Мельничук, Н. М. Мельникова, Є. А. Деркач // Український біохімічний журнал. - 2004. - С. 95-99.

3. Гутий Б. В. Вплив хлориду кадмію у різних дозах на активність амінотрансфераз сироватки крові бугайців / Б. В. Гутий // Науковий вісник Львівського національного університету ветеринарної медицини та біотехнологій ім. Гжицького. -2013 . - Т. 15, № 1(1). - C. 49-52.

4. Засєкін Д. А. Вплив хронічного токсикозу через забруднення важкими металами на клінічні показники та стан кислотно-лужної рівноваги крові корів / Д. А. Засєкін, М. Д. Засєкін // Вет. мед. України. - 2003. - № 12. - С. 33-34.

5. Боріков О. Ю. Вплив хлориду кадмію та пероксиду водню на процеси пероксидного окислення і фракційний склад ліпідів у гепатоцитах щурів / О. Ю. Боріков, П. А. Каліман // Укр. біохім. журн. - 2004. - Т. 76, № 2. - С. 107-111.

6. Гутий Б. В. Вплив хлориду кадмію у токсичних дозах на глутатіонову систему антиоксидантного захисту організму бичків / Б. В. Гутий // Ветеринарна біотехнологія. -2013. - Вип. 22. - С. 112-116.

7. Гутий Б. В. Вплив мевеселу та Е-селену на рівень показників не ферментної системи антиоксидантного захисту організму бугайців при кадмієвому навантаженні / Б. В. Гутий // Ветеринарна медицина. - 2013. - Вип. 97. - С. 419-421.

8. Довідник: Фізіолого-біохімічні методи досліджень у біології, тваринництві та ветеринарній медицині / Відпов. редак. В. В. Влізло. - Львів, 2004. - 399 с.

9. Куртяк Б. М. Вміст вітамінів А і Е та продуктів перекисного окиснення ліпідів у плазмі крові корів при парентеральному введені тривіту і інсолвіту в кінці стійлового періоду // Наук.- техн. бюл. Ін-ту біол. тварин. - Львів, 2006. - С. 212-214.

10. Дрошнев A. E. Влияниевитамина Е на показатели перекисного окисления липидов и антиоксидантной защиты у рыб при стрессе / А. Е. Дрошнев, М. Н. Борисова, Н. А. Костромитинов // Міжвідомчий тематичний науковий збірник "Ветеринарна медицина" Харків, 2005. - Т. 1. - С. 395-398.

11. Гутий Б. В. Вплив мевеселу на вміст вітамінів А і Е у крові бичків за умов кадмієвої інтоксикації / Б. В. Гутий // Науковий вісник Львівського національного університету ветеринарної медицини та біотехнологій ім. Гжицького. - 2013. - Т. 15, № 3(1). - С. 78-82.

12. Баглай О. М. Система антиоксидантного захисту та перекисне окиснення ліпідів організму тварин / О. М. Баглай, С. Д. Мурська, Б. В. Гутий // Наук. вісник Львівського національного університету ветеринарної медицини та біотехнологій імені С. 3. Гжицького. Львів, 2011. - Т. 13, № 4(50), Ч. 2. - С. 3-11.

\section{References}

1. Melnychuk, D. O. Trakhtenberh I. M., Melnykova N. M., Kalinin I. V., Shepelova I. A., \& Derkach Ye. A. (2002). Toksykolohichnyi vplyv solei svyntsiu ta kadmiiu na bioikhimichni pokaznyky u laboratornykh tvaryn. Naukovyi visnyk NAU, 55, 117-119 (in Ukrainian).

2. Melnychuk, D. O., Melnykova, N. M., \& Derkach, Ye. A. (2004). Vikovi osoblyvosti kumuliatsii kadmiiu v orhanakh otruienykh shchuriv i zminy pokaznykiv kyslotnoluzhnoho stanu 
krovi za riznykh umov antyoksydantnoho zakhystu orhanizmu. Ukrainskyi biokhimichnyi zhurnal, 95-99 (in Ukrainian).

3. Hutyi, B. V. (2013). Vplyv khlorydu kadmiiu u riznykh dozakh na aktyvnist aminotransferaz syrovatky krovi buhaitsiv. Naukovyi visnyk Lvivskoho natsionalnoho universytetu veterynarnoi medytsyny ta biotekhnolohii im. Gzhytskoho, 15, 1(1), 49-52 (in Ukrainian).

4. Zasiekin D. A., \& Zasiekin, M. D. (2003). Vplyv khronichnoho toksykozu cherez zabrudnennia vazhkymy metalamy na klinichni pokaznyky ta stan kyslotno-luzhnoi rivnovahy krovi koriv. Vet. med. Ukrainy, 12, 33-34 (in Ukrainian).

5. Borikov, O. Yu., \& Kaliman, P. A. (2004). Vplyv khlorydu kadmiiu ta peroksydu vodniu na protsesy peroksydnoho okyslennia i fraktsiinyi sklad lipidiv u hepatotsytakh shchuriv. Ukr. biokhim. Zhurn, 76(2), 107-111 (in Ukrainian).

6. Hutyi, B. V. (2013). Vplyv khlorydu kadmiiu u toksychnykh dozakh na hlutationovu systemu antyoksydantnoho zakhystu orhanizmu bychkiv. Veterynarna biotekhnolohiia, 22, 112-116 (in Ukrainian).

7. Hutyi, B. V. (2013). Vplyv meveselu ta E-selenu na riven pokaznykiv ne fermentnoi systemy antyoksydantnoho zakhystu orhanizmu buhaitsiv pry kadmiievomu navantazhenni. Veterynarna medytsyna, 97, 419-421 (in Ukrainian).

8. Vlizlo, V. V. (20040. Dovidnyk: Fizioloho-biokhimichni metody doslidzhen u biolohii, tvarynnytstvi ta veterynarnii medytsyni. Lviv (in Ukrainian).

9. Kurtiak, B. M., \& Yanovych, V. H. (2006). Vmist vitaminiv A i E ta produktiv perekysnoho okysnennia lipidiv u plazmi krovi koriv pry parenteralnomu vvedeni tryvitu i insolvitu v kintsi stiilovoho periodu. Nauk.-tekhn. biul. In-tu biol. tvaryn. Lviv, 212-214 (in Ukrainian).

10. Droshnev, A. E., Borisova, M. N., \& Kostromitinov, N. A. (2005). Vlijanievitamina E na pokazateli perekisnogo okislenija lipidov i antioksidantnoj zashhity u ryb pri stresse. Mizhvidomchij tematichnij naukovij zbirnik "Veterinarna medicina". Harkiv, 1, 395-398 (in Russian).

11. Hutyi, B. V. (2013). Vplyv meveselu na vmist vitaminiv A i E u krovi bychkiv za umov kadmiievoi intoksykatsii. Naukovyi visnyk Lvivskoho natsionalnoho universytetu veterynarnoi medytsyny ta biotekhnolohii im. Gzhytskoho, 15, 3(1), 78-82 (in Ukrainian).

12. Bahlai, O. M., Murska, S. D., \& Hutyi, B. V. (2011). Systema antyoksydantnoho zakhystu ta perekysne okysnennia lipidiv orhanizmu tvaryn. Nauk. visnyk Lvivskoho natsionalnoho universytetu veterynarnoi medytsyny ta biotekhnolohii imeni S. Z. Gzhytskoho, 13, 4(50), 2, 3-11. (in Ukrainian).

Рецензент - М. І. Жила, д. вет. н., доцент, ДНДКІ ветпрепаратів та кормових добавок. 